\title{
PERAN BELAJAR MATEMATIKA TERHADAP KONSISTENSI DIRI SISWA (Survei Terhadap Siswa-siswi Sekolah Menengah Atas di Kabupaten Karawang Tahun 2010/2011)
}

\author{
LEONARD \\ leonard@unindra.net \\ Program Studi Pendidikan Matematika, Fakultas Teknik, Matematika dan IPA \\ Universitas Indraprasta PGRI
}

SITTA KHOMSATUN SUPRIYATI

sitasitta@ymail.com

Mahasiswa Program Studi Pendidikan Matematika,

Fakultas Teknik, Matematika dan IPA

Universitas Indraprasta PGRI

\begin{abstract}
The aim of this research is to know the influence of learning result (achievement) toward the self-consistency of the students in senior high school in Karawang. The research method wich was used in the research is survey method. The population of research are all sudents in senior high school in Karawang, West Java. Samples are taken by multi stage sampling, consisted of 120 students. The research instruments are self-consistency. Data analysis employed regretion correlation. The hypothesis testing resulted conclution: there positive correlation of studied mathematics achievement toward the self-consistency.
\end{abstract}

Key Words: mathematics learning, achievement, self-consistency.

\section{PENDAHULUAN}

Pendidikan merupakan suatu hal yang sangat penting dalam proses perbaikan mutu hidup dalam bermasyarakat. Di era globalisasi saat ini, terjadi perubahan yang signifikan dalam kehidupan bermasyarakat. Kita tidak dapat menghindar dari arus globalisasi yang memaksa kita untuk masuk ke kehidupan yang modern. Di era globalisasi ini terjadi perubahan nilai-nilai kehidupan dan oleh sebab itu juga terjadi perubahan dalam proses perbaikan mutu kehidupan. Salah satu yang tidak terlepas dalam perubahan tersebut adalah pendidikan.

Berbicara mengenai pendidikan tidak terlepas dari kebijakan pendidikan dan tujuan pendidikan. Tujuan pendidikan nasional telah dirumuskan melalui UU No 20 tahun 2003 tentang Sistem Pendidikan Nasional. "Ada dua tujuan pendidikan nasional sebagaimana yang tersirat dalam UUD 1945, yaitu: pendidikan yang mencerdaskan kehidupan bangsa, pendidikan adalah hak seluruh rakyat" (Tilaar, 2003:6). Bangsa yang cerdas di sini maksudnya adalah bangsa yang berdiri sendiri (merdeka), dapat memilih mana yang baik dan berguna bagi bangsanya dan tidak hanya dapat bekerja tetapi dapat pula menciptakan lapangan pekerjaan.

Masih dalam buku yang sama (2003:60) Tilaar menuliskan bahwa dalam institusi pendidikan masyarakat modern saat ini, perlulah dikaji hal-hal berikut: organisasi lembaga pendidikan, kepemimpinan, kurikulum, proses belajar dan kontrol. Kelima aspek itulah yang selalu dikaji oleh negara-negara maju agar bisa menghasilkan sumber daya manusia yang berkualitas tinggi. Karena sumber daya manusia yang berkualitas adalah salah satu modal untuk bisa bersaing di era globalisasi saat ini. Menurut laporanlaporan Human Development Report yang dikutip oleh Tilaar (2003:227), "negara-negara 
maju terus-menerus serta konsisten memperbaiki kualitas sumber daya manusia melalui pendidikan, kesehatan dan kebutuhan-kebutuhan asasi manusia”. Dalam kata lain, mereka saja yang sudah maju masih dan terus memperhatikan mutu pendidikan.

Hal itulah yang belum dimiliki oleh Indonesia. Pemerintah yang memegang amanat serta peran besar dalam maju tidaknya pendidikan Indonesia belum mampu merealisasikan apa yang tertuang dalam UUD 1945 tentang pendidikan nasional. Lebih parahnya lagi, saat ini Indonesia sedang mengalami krisis yang disebabkan oleh merajalelanya korupsi, kolusi dan nepotisme (KKN) yang bukannya semakin menghilang namun sebaliknya semakin merajalela. Saat ini KKN sudah menjadi budaya baru Indonesia. Dari manakah kita harus memulai memberantas penyakit masyarakat ini? Jawabannya adalah dari diri kita sendiri. Perlu kesadaran moral serta konsistensi dari diri kita untuk mengubahnya menjadi lebih baik.

Menyinggung masalah konsisten, bisakah semua orang konsisten dengan apa yang dikatakan serta diperbuat? Jawabannya pasti bisa. Namun, tidak semuanya mau untuk konsisten. Kita bisa melihat contohnya ketika musim pemilu datang. Dimana para calon anggota dewan yang terhormat berbondong-bondong mengampanyekan programprogram pro-rakyat. Namun, apa yang terjadi ketika mereka sudah terpilih? Tidak sedikit diantara mereka yang melupakan janji-janji mereka itu. Ini adalah salah satu bentuk ketidak konsistenan yang dimiliki oleh masyarakat Indonesia.

Konsisten bukan timbul begitu saja. Perlu waktu untuk menjadikan seseorang itu menjadi konsisten atau mendekati konsisten. Kebiasaan bisa saja menjadi awal dimana diri ini menjadi sosok yang konsisten. Dimana dengan kebiasaan hidup yang disiplin, terencana serta fokus, diharapkan bisa melatih kita menjadi seseorang yang konsisten.

Sebagai salah satu mata pelajaran yang wajib diberikan pada setiap jenjang pendidikan sebagaimana yang dinyatakan dalam UU No. 23 Tahun 2003 tentang Sistem Pendidikan Nasional, Pasal 31 ayat 1 yang menyatakan bahwa "kurikulum pendidikan dasar dan menengah wajib memuat pendidikan matematika" (Lembaga Negara Republik Indonesia, 2003:17), tentu saja matematika memiliki peranan penting. Hal ini disebabkan karena matematika adalah ilmu dasar yang bisa membentuk seseorang agar dapat memahami dan menguasai permasalahan sosial dan alam. Tak heran banyak pendapat bahwa seseorang yang memiliki nilai matematika tinggi memiliki kecerdasan lebih tinggi dibandingkan dengan seseorang yang nilai matematikanya biasa-biasa saja.

Jika kita hubungkan antara matematika dan konsistensi, sepertinya dua kata ini memiliki keterkaitan yang sangat erat. Matematika adalah ilmu yang sistematik dan terstruktur. Sehingga orang yang mempelajarinya diharapkan bisa menjadi seseorang yang lebih terstruktur serta terencana. Seseorang yang memiliki konsistensi diri yang baik memiliki pandangan hidup yang jelas dan terarah. Untuk itu biasanya mereka akan selalu membuat rencana-rencana untuk setiap apa yang akan mereka lakukan. Bisa dikatakan bahwa seseorang yang mempelajari matematika secara tidak langsung dia sedang belajar untuk menjadi seseorang yang konsisten.

\section{TINJAUAN PUSTAKA}

\section{Konsistensi diri}

Menurut Arianto (2008) "konsistensi adalah keteguhan hati terhadap tujuan, dan usaha/pengembangan yang tak berkesudahan, tetaplah diperlukan walau seseorang telah berhasil mencapai target-target dalam hidupnya”. Bagi mereka yang memiliki konsistensi tinggi, mereka tidak akan mudah putus asa apabila dihadapi rintangan pada saat melakukan pekerjaan.

Masih menurut Arianto (2008), ada beberapa hal yang dibutuhkan untuk menjaga konsistensi, antara lain: motif, kesadaran dan introspeksi. 
Reza M Syarif (2005:31) dalam bukunya yang berjudul Life Excellent mengatakan bahwa "konsisten adalah fokus pada suatu bidang. Kita tidak akan berpindah dari bidang lain sebelum bidang pertama kuat". Dengan konsisten kita akan mendapatkan: (1) Quantum leap process, yaitu percepatan-percepatan dalam kehidupan. (2) Out standing achievement, yaitu prestasi yang diatas rata-rata.

Konsisten ini mengajarkan kita untuk melaksanakan kewajiban-kewajiban kita baru kita bisa mendapatkan hak-hak kita. Kalau hal ini diterapkan dalam kehidupan sehari-hari khususnya dalam hal belajar kita, kita akan menjadi pribadi yang unggul baik dalam akademik maupun non akademik, serta kita akan mengalami percepatanpercepatannya. Dengan kata lain konsisten akan memberikan kekuatan kepada diri kita.

Menurut Prabowo (2008) "konsistensi diri adalah representatif dari kekuatan iman, yaitu kekonsistenan antara pikiran, perkataan, dan perbuatan, serta keserasian dari pengetahuan, ketauladanan sikap dan tekad awal untuk menyeru". Konsistensi dalam belajar merupakan pembuktian waktu, pembuktian pada kondisi, bahwa seperti apapun kondisinya dan berapa lama waktu yang dibutuhkan, belajar tidak akan pernah berhenti.

Untuk membentuk konsistensi diri dibutuhkan pemahaman yang integral terkait dengan tujuan belajar dan dibutuhkan imunitas. Oleh karena itu, dibutuhkan pembinaan yang dilakukan secara berkala dan kontinu. Konsisten dalam belajar bukan berarti keadaan yang stagnan, tidak berubah. Tetapi, bila terkait dengan strategi ini merupakan keadaan yang dinamis. Perubahan yang selalu menuju kebaikan.

"Konsisten adalah ketetapan dan kemantapan dalam bersikap atau bertindak, atau selalu sesuai antara perbuatan dengan ucapan” (Lontong,2010). Misalnya, kita memasang target akan belajar 1 jam sehari, atau akan bangun pagi setiap harinya, namun kenyataannya bisa diluar target bahkan tidak sama sekali. Hal ini dipengaruhi oleh faktorfaktor baik dari dalam maupun luar diri kita. Faktor nafsu atau keinginan menjadi faktor penghambat utama.Faktor kedisiplinan tak kalah penting dalam halnya membangun konsistensi, dimana kedisiplinan merupakan salah satu kunci dari keberhasilan.

Menurut Abdullah (2010) ada 5 cara menjaga diri kita agar tetap konsisten, yaitu: (1) Murokobah, mengenali betul apa yang ditekuninya. Mengenali disini adalah kita harus tahu benar seluk beluk akan apa yang akan kita kerjakan, manfaat apa yang akan didapatkan, ataupun dampak negatif / kerugian apa yang akan didapat. (2) Muahadah, disiplin untuk dilakukan. Baik emosi sedang bagus maupun tidak. (3) Muhasabah, cek lagi dan lagi. (4) Muakobah, penghukuman dan pemberian hadiah kepada diri sendiri. Saat kita memberikan hadiah pada diri kita, dapat menimbulkan kepercayaan diri bahwa kita bisa. (5) Mujahadah, pengoptimalan, memperbaiki terus-menerus. Kita mungkin sering merasa bahwa apa yang kita dapat tidak sesuai dengan harapan kita, namun kita harus menjadikannya modal dan terus memperbaiki hingga hasil maksimal dapat tercapai.

Menurut Abelson dkk yang dikutip oleh Eunkook M. Suh (2002:1378) dalam artikel yang berjudul Culture, Identity Consistency, and Subjective Well-Being mengatakan bahwa "konsistensi diri adalah syarat untuk menuju kesejahteraan. Orang yang memiliki konsistensi diri cenderung lebih luas pengetahuannya, lebih tegas".

Berdasarkan uraian di atas, maka penulis menyimpulkan bahwa konsistensi diri adalah sikap dimana pikiran, perkataan, dan perbuatan kita selaras dan tetap, namun bisa fleksibel untuk mencapai suatu tujuan yang telah kita rancang sebelumnya.

\section{Prestasi Belajar Matematika}

Prestasi belajar matematika adalah sebuah kalimat yang terdiri dari tiga kata yaitu prestasi, belajar dan matematika. Antara kata prestasi, belajar dan matematika mempunyai arti yang berbeda. Oleh karena itu, sebelum kita mengartikan prestasi belajar matematika, ada baiknya pembahasan ini diarahkan pada masing-masing permasalahan 
terlebih dahulu untuk mendapatkan pemahaman lebih jauh mengenai makna kata prestasi belajar. Hal ini juga untuk memudahkan dalam memahami lebih mendalam tentang pengertian prestasi belajar itu sendiri.

"Prestasi adalah hasil dari suatu kegiatan yang telah dikerjakan, diciptakan baik secara individu maupun secara kelompok" (Djamarah, 2006:19). Sedangkan menurut Mas'ud Hasan Abdul Dahar dalam Djamarah (2006:21) bahwa "prestasi adalah apa yang telah dapat diciptakan, hasil pekerjaan, hasil yang menyenangkan hati yang diperoleh dengan jalan keuletan kerja". Adapun prestasi dapat diartikan sebagai hasil yang diperoleh karena adanya aktivitas belajar yang telah dilakukan.

Menurut Skinner yang dikutip oleh Dimyati dan Mudjiono (2002:250), "belajar adalah suatu perilaku. Pada saat orang belajar, maka responnya menjadi lebih baik". Sebaliknya, bila ia tidak belajar maka responsnya menurun. Sedangkan Gagne (Dimyati dan Mujdiono, 2002:251) berpendapat bahwa "belajar adalah kegiatan yang kompleks". Setelah belajar orang memiliki keterampilan, pengetahuan, sikap, dan nilai.

Manusia belajar karena terdorong oleh beberapa keinginan, yaitu: adanya dorongan rasa ingin tahu, tuntutan zaman dan lingkungan, adanya kebutuhan yang harus dipenuhi, untuk mengetahui sesuatu yang belum diketahui atau menyempurnakannya, untuk mampu bersosialisasi dan beradaptasi dengan lingkungannya, untuk meningkatkan kualitas dan mengembangkan potensi diri, mengisi waktu luang, mencapai cita-cita.

Slameto (2003:112) berpendapat bahwa, "belajar adalah suatu proses usaha yang dilakukan oleh seseorang untuk memperoleh suatu perubahan tingkah laku yang baru saja secara keseluruhan, sebagai hasil pengalamannya sendiri dalam interaksi dengan lingkungannya". Terdapat beberapa faktor yang mempengaruhi belajar, yaitu: (1) Faktor internal, yaitu faktor yang ada dalam diri individu, seperti faktor kesehatan, kecerdasan, minat, bakat, kematangan. (2) Faktor eksternal, yaitu faktor yang ada di luar diri individu, seperti faktor keluarga/cara orang tua mendidik, faktor sekolah, metode mengajar, alat peraga, teman bergaul, dll.

Manusia belajar melalui interaksi dengan lingkungan sekitarnya. Lingkungan pertama manusia belajar adalah keluarganya. Lalu setelah keluarga dilanjutkan dengan belajar pada lingkungan sekitar tempat tinggal, lingkungan sekolah, dan seterusnya. Melalui proses belajar tersebut seseorang mengalami berbagai pengalaman yang akhirnya akan mempengaruhi tingkah laku dan perbuatan. Namun, tidak dapat di lupakan juga faktor keturunan atau warisan yang dapat mempengaruhi sifat dan kepribadian.

Howard L. Kingsleny dalam Baharuddin (2009:65) menjelaskan bahwa "belajar adalah proses ketika tingkah laku (dalam arti luas) ditimbulkan atau diubah melalui praktik atau latihan".

Prestasi belajar di bidang pendidikan adalah hasil dari pengukuran terhadap peserta didik yang meliputi faktor kognitif, afektif dan psikomotor setelah mengikuti proses pembelajaran yang diukur dengan menggunakan instrumen tes atau instrumen yang relevan.

Berdasarkan teori-teori di atas maka dapat disimpulkan bahwa prestasi belajar adalah perubahan yang dihasilkan setelah terjadinya proses belajar. Dimana hasil belajar tidak hanya berupa nilai semata, namun hasil belajar dapat dilihat, dirasakan dan dimanfaatkan untuk kehidupan mendatang.

Banyak definisi tentang matematika, baik dari para ahli maupun masyarakat umum lainnya. Oleh karenanya matematika tidak akan pernah selesai untuk didiskusikan. Menurut sudut pandang Andi Hakim Nasution yang dikutip oleh Abdul Halim Fatani (2009:2) kata matematika berasal dari kata Yunani yaitu mathein atau manthenein yang berarti mempelajari. Kata ini memiliki hubungan yang erat dengan kata sanskerta, medha atau widya yang memiliki arti kepandaian, ketahuan, atau intelegensia. Dalam bahasa 
Belanda, matematika disebut dengan kata wiskunde yang berarti ilmu tentang belajar (hal ini sesuai dengan arti kata mathein pada matematika).

Menurut Johnson dan Rising (Ruseffendi, 1996:3) "matematika adalah pola berfikir, pola mengorganisasikan pembuktian yang logik". Matematika adalah bahasa yang menggunakan istilah dengan cermat, cerdas dan akurat, representasinya dengan simbol dan padat, lebih berupa bahasa simbol mengenai ide (gagasan) dari pada mengenai bunyi. Matematika juga merupakan pengetahuan struktur yang terorganisasikan sifat-sifat atau teori-teori itu dibuat secara deduktif berdasarkan kepada unsur-unsur yang didefinisikan atau tidak terdefinisi.

Reys dkk (Ruseffendi, 1996:3) mengatakan bahwa "matematika adalah telaahan tentang pola dan hubungan, suatu jalan atau pola berpikir, suatu seni, suatu bahasa dan suatu alat".

Kemudian Kline (dalam Ruseffendi, 1996:3) berpendapat bahwa "matematika itu bukanlah pengetahuan menyendiri yang dapat sempurna karena dirinya sendiri, tetapi adanya matematika itu terutama untuk membantu manusia agar dapat memahami dan menguasai permasalahan sosial ekonomi dan alam".

Sedangkan Ruseffendi (1996:4) sendiri mengartikan "matematika sebagai bahasa, seni dan ratunya ilmu. Matematika juga merupakan ilmu tentang struktur yang terorganisasi dengan baik serta ilmu tentang pola dan hubungan".

Dari beberapa teori di atas maka penulis menyimpulkan bahwa prestasi belajar matematika adalah perubahan yang terjadi pada siswa setelah terjadinya proses belajar mengajar matematika yang ditandai dengan ingatan, pemahaman, dan penerapan atas matematika.

\section{METODE}

Penelitian dilaksanakan di Sekolah Menengah Atas di Kabupaten Karawang, dimana di Kabupaten Karawang terdapat 32 Sekolah Menengah Atas Negeri dengan perincian 19 SMAN, 9 SMKN dan 4 MAN. Pelaksanaan penelitian dilaksanakan dalam waktu enam bulan pada tahun 2011.

Metode yang digunakan dalam penelitian ini adalah metode survei dengan teknik analisis regresi korelasi. Populasi dalam penelitian ini adalah siswa-siswi Sekolah Menengah Atas Negeri di Kabupaten Karawang. Sedangkan sampel diambil 120 siswa dari populasi, dengan teknik multi stage sampling. Teknik ini dilakukan dengan beberapa tahap, yaitu: tahap pertama memilih 3 Sekolah Menengah Atas dari 32 Sekolah Menengah Atas yang ada, yaitu 1 SMAN, 1 SMKN dan 1 MAN; tahap kedua adalah memilih secara acak masing-masing 40 siswa dari ketiga Sekolah Menengah Atas Negeri tersebut, sehingga didapat sampel sebanyak 120 orang.

Pengumpulan data dilakukan dengan menggunakan instrumen penilaian untuk variabel konsistensi diri sebanyak 24 item berbentuk skala likert. Sedangakan untuk variabel prestasi belajar, pengumpulan data melalui dokumen guru bidang studi. Selanjutnya data yang diperoleh diolah dan dianalisis menggunakan teknik pengujian analisis regresi korelasi.

\section{HASIL DAN PEMBAHASAN \\ Data Prestasi Belajar Matematika}

Dari hasil dokumentasi prestasi belajar matematika terhadap 120 siswa yang dijadikan sampel penelitian, diperoleh data skor maksimum 85 dan skor minimum 10, sehingga diperoleh rentang ( jangkauan) data sebesar 75. Berdasarkan hasil analisis data, diperoleh modus 64,28, median 54,95, rata-rata 50, simpangan baku 19. Dari rentang skor teoritik antara 10 sampai dengan 85. Mayoritas siswa (sebesar 36,7\%) memiliki skor 
prestasi belajar matematika dalam rentang antara 60 sampai 69 dari skor maksimum 85 . Dengan demikian data tergolong baik dan tidak banyak beragam.

\section{Data Konsistensi Diri}

Dari hasil pengukuran Konsistensi Diri terhadap 120 siswa, diperoleh skor maksimum 119 dan skor minimum 52. Dari hasil perhitungan diperoleh modus 93,13, median 90,68, rata-rata 88,18, simpangan baku 16,15; dari rentang skor 52 sampai dengan 119. Mayoritas siswa $(28,3 \%)$ memiliki skor konsistensi diri dalam rentang antara 88 sampai dengan 96 dari skor maksimum 119. Data penelitian juga menunjukkan bahwa seluruh siswa (100\%) memiliki skor konsistensi diri di atas 50, artinya semua siswa telah memiliki konsistensi diri di atas $41,7 \%$ dari skor teoritik yang diharapkan (120). Bahkan data menunjukkan $60 \%$ siswa memiliki skor konsistensi diri diatas 85 (73\%), hal ini berarti bahwa $60 \%$ siswa telah memiliki konsistensi diri sebanyak $73 \%$ dari skor teoritik maksimum (120). Dengan demikian data tergolong baik dan tidak banyak beragam.

\section{Uji Persyaratan Analisis Data}

Data yang telah dikumpulkan selanjutnya diuji persyaratan analisis, yang meliputi uji normalitas dan uji linieritas. Hasil pengujian normalitas menggunakan uji Liliefors diperoleh hasil bahwa seluruh variabel berdistribusi normal. Hasil pengujian linieritas menggunakan tabel bantuan ANOVA diperoleh hasil bahwa persamaan regresi yang terbentuk antara kedua variabel adalah linier, sehingga dapat dilanjutkan menggunakan statistik parametrik, dengan korelasi dan regresi linier sederhana.

\section{Pengujian Hipotesis Penelitian}

Korelasi sederhana untuk mengetahui tingkat keeratan hubungan antara variabel X dan variabel $\mathrm{Y}$ dalam penelitian ini digunakan rumus Korelasi Product Moment. Dari perhitungan didapat nilai $r_{x y}=0,3$. Artinya dari hasil penelitian berasumsi bahwa prestasi belajar matematika siswa mempengaruhi konsistensi diri.

Pengujian signifikansi koefisien korelasi antara variabel $\mathrm{X}$ dan variabel $\mathrm{Y}$ dalam penelitian ini diuji melalui uji hipotesis (uji t). Dari hasil perhitungan, maka didapat $t_{\text {hitung }}$ $=3,42$ sedangkat $t_{\text {tabel }}=1,66$ pada taraf nyata $95 \%$. Sehingga dapat disimpulkan bahwa terdapat pengaruh yang signifikan antara prestasi belajar matematika terhadap konsistensi diri.

Untuk mengetahui besarnya kontribusi pengaruh prestasi belajar matematika terhadap konsistensi diri dilakukan dengan menggunakan uji koefisien determinasi, dari perhitungan didapat $\mathrm{KD}=9 \%$. Jadi pengaruh prestasi belajar matematika terhadap konsistensi diri sebesar $9 \%$ dan sisanya dipengaruhi oleh faktor lain.

Persamaan regresi yang terbentuk adalah $\mathrm{Y}=79,75+0,25 \mathrm{X}$, yang dapat diartikan jika prestasi belajar diabaikan maka konsistensi diri siswa sebesar 79,75; dan setiap penambahan 1 point pada prestasi belajar matematika, akan menambah konsistensi diri siswa sebesar 0,25 point.

Untuk pengujian keberartian regresi dilakukan dengan uji $\mathrm{F}$ untuk taraf nyata $\alpha=5 \%$ dk pembilang $=1$, dk penyebut $=120-2=118$ diperoleh $\mathrm{F}_{\text {tabel }}=$ 3,92 dan $F_{\text {hitung }}=351,11$. Perhitungan lengkap dapat dilihat di halaman 56-59. Karena $\mathrm{F}_{\text {hitung }}>\mathrm{F}_{\text {tabel }}$ maka $\mathrm{H}_{0}$ ditolak yang berarti koefisien arah regresi berarti.

\section{Pembahasan Hasil Penelitian}

Setelah dilakukan rangkaian penelitian maka dapat disimpulkan bahwa terdapat pengaruh antara prestasi belajar matematika siswa terhadap konsistensi 
diri. Hal ini sangat logis karena sewaktu kita belajar matematika kita sudah berlatih menjadi sesorang yang konsisten. Dimana matematika adalah ilmu yang sistematik, terstruktur dan terkonsep sehingga secara tidak langsung kita terlatih untuk menjadi orang yang yang sistematik pula.

Konsistensi diri akan lebih maksimal jika pemahaman konsep tertata dengan baik, hal ini menuntut prestasi belajar matematika yang merupakan salah satu potensi yang harus dikembangkan oleh siswa serta aplikasi dari ilmu matematika itu sendiri. Sehingga wajar jika prestasi belajar matematika mempengaruhi konsistensi diri.

Prestasi belajar matematika memberikan kontribusi $9 \%$ terhadap konsistensi diri sedangkan sisanya $91 \%$ ditentukan oleh faktor lainnya. Ini membuktikan bahwa secara tidak langsung prestasi belajar matematika mempengaruhi konsistensi diri siswa. Dengan kata lain bahwa siswa yang memiliki prestasi belajar matematika baik akan memiliki sikap konsistensi diri yang baik pula, begitupun sebaliknya.

Namun, dilihat dari besarnya nilai kontribusi yang tak terlalu besar ini menyadarkan kita bahwa untuk menjadi seorang yang memiliki konsistensi diri tinggi tidaklah dilihat dari prestasi belajar matematikanya saja. Ada banyak faktor lain baik dari dalam diri maupun lingkungan sekitar. Walau sejak dini kita sudah terlatih untuk menyelesaikan masalah-masalah matematika dengan rumus-rumus yang sistematik, bukan berarti kita bisa menyelesaikan masalah-masalah dalam kehidupan sehari-hari dengan sistematik pula. Banyak pertimbanganpertimbangan yang mempengaruhi sikap apa yang akan diambil dalam menyelesaikan permasalahan sehari-hari. Pertimbangan-pertimbangan itulah yang menjadi faktor lain dalam terciptanya konsistensi diri yang baik.

Penelitian ini membuktikan pendapat Prabowo (2008) mengenai konsistensi diri. Ia mengatakan bahwa "konsistensi diri adalah representatif dari kekuatan iman, yaitu kekonsistenan antara pikiran, perkataan, dan perbuatan, serta keserasian dari pengetahuan, ketauladanan sikap dan tekad awal untuk menyeru". Hal ini sangatlah wajar karena untuk mencapai konsistensi diri yang baik dibutuhkan keserasian dari pengetahuan, ketauladanan sikap dan tekad awal. Sehingga bagi siswa yang memiliki prestasi belajar matematika yang baik perlulah diimbangi dengan sikap dan niat awal yang baik pula, salah satunya adalah memahami serta menerapkan nilai-nilai yang terkandung dalam ilmu matematika.

Penelitian ini juga selaras dengan pendapat Arianto (2008), yaitu "ada beberapa hal yang dibutuhkan untuk menjaga konsistensi, antara lain: motif, kesadaran dan introspeksi". Motif atau niat merupakan awal mula seseorang untuk beraktifitas. Sadar atau tidak pastilah dalam melakukan sesuatu setiap orang memiliki niat baik itu terselubung atau tidak, entah niat itu bertujuan baik atau sebaliknya. Namun, untuk menjadi seseorang yang memiliki konsistensi diri yang baik diperlukan niat yang sungguh-sungguh agar ia tidak tergoda ditengah jalan. Sehingga apa yang ia niatkan yaitu menjadi seseorang yang konsisten dapat tercapai. Dan semuanya itu bisa tercapai ketika kita sadar betul apa tujuan serta apa yang harus kita lakukan. Sehingga tak salah bila kesadaran merupakan hal yang dibutuhkan dalam menjaga konsistensi diri. 
Hal yang tak kalah penting adalah introspeksi diri. Hal inilah yang jarang bahkan sering sekali dilupakan oleh masyarakat Indonesia. Dimana apabila kita mengalami kegagalan jaganlah kita lantas menyerah pada nasib. Kita haruslah introspeksi yaitu mengevaluasi apa saja yang telah kita lakukan. Introspeksi yang baik bukan hanya dilakukan apabila kita mengalami kegagalan saja, namun ketika kita mengalami keberhasilan harus diadakan introspeksi pula sehingga keberhasilan itu dapat terulang lagi. Namun hal itu sangatlah sulit. Jagankan ketika kita berhasil, ketika kita mengalami kegagalan saja banyak orang yang langsung menyerah begitu saja, melupakan niat awalnya. Niat awal untuk konsisten.

Konsisten bukan sekadar berbuat sesuatu secara terus-menerus dan berkelanjutan seperti halnya mengerjakan soal matematika. Dimana dalam belajar matematika kita disajikan rumus-rumus untuk dapat menyelesaikan soal tersebut. Namun, konsistensi diri adalah sikap dimana pikiran, perkataan dan perbuatan kita selaras dan tetap, namun bisa fleksibel untuk mencapai tujuan yang telah kita rancang atau niatkan dari awal. Sehingga kita tidak boleh terpaku oleh keadaan yang ada.

\section{PENUTUP}

\section{Kesimpulan}

Dari hasil analisis dan pengujian hipotesis di atas dapat ditarik kesimpulan terdapat pengaruh positif antara prestasi belajar matematika terhadap konsistensi diri, walaupun pengaruhnya tidak terlalu besar. Kesimpulan ini didukung oleh hasil pengujian signifikansi antara prestasi belajar matematika dengan konsistensi diri yang hasilnya menunjukkan ada pengaruh signifikan.

\section{Saran}

Dari hasil penelitian tersebut diketahui terdapat korelasi antara prestasi belajar matematika dengan konsistensi diri pada Sekolah Menengah Atas Negeri di Kabupaten Karawang. Perlu upaya untuk memahami peran serta kegunaan belajar matematika sehingga dapat meninggkatkan konsistensi diri siswa. Disini peran guru sangatlah penting dalam pengarahan serta menciptakan lingkungan belajar yang kondusif. Dimana dalam belajar matematika bukanlah sekedar pencapaian nilai yang maksimal, namun harus diikuti oleh prinsip sikap dari matematika itu sendiri yang harus dipahami oleh setiap siswa. Untuk itu guru dituntut untuk lebih kreatif dalam mengajar. Dengan demikian diharapkan peningkatan konsistensi diri dapat terwujud dengan belajar matematika.

\section{DAFTAR PUSTAKA}

Abdullah, Khaliludin. 5 Cara Menjaga Konsistensi. (http://khalidabdullah.com/ pembelajaran/5-cara-bagaimana-tetap-konsisten/)

Alim, M. Baitul. 2009. (http://www.psi kologizone.com/faktor-yang-mempengaru hiprestasi-belajar-anak)

Arianto, Erwin. Konsisten (http://www.wikimu.com/News/Print.aspx?id=6350)

Arikunto, Suharsimi. Dasar-Dasar Evaluasi Pendidikan. Jakarta: Bumi Aksara. 2006. Prosedur Penelitian Suatu Pendekatan Praktis. Jakarta: Rineka Cipta. 
Baharuddin. 2009. Pendidikan \& Psikologi Perkembangan. Jogjakarta: Ar-Ruzz Media.

Depdiknas-Dirjen Dikdasmen.2003. Undang-Undang RI Tentang Sistem Pendidikan Nasional. Jakarta: Depdiknas.

Dimyati dan Mujdiono. 2002. Belajar dan Pembelajaran. Jakarta: Rineka Cipta.

Djamarah, Syaiful Bahri dan Zain, Aswan. 2006. Strategi Belajar Mengajar. Jakarta: Rineka Cipta.

Fathani, Abdul Halim. 2009. Matematika Hakikat \& Logika. Jogjakarta:Ar-Ruzz Media.

Ihsan, Helli. 2009. Pengukuran (http://www.linkpdf.com/ ebookviewer. php?url=http:// file.upi.edu/ Direktori/A\%20\%20FIP/JUR.\%20PSIKOLOGI /197509122 006041\% 20\%20HELLI\%20IHSAN/ Pengertian\%20Pengukuran.pdf)

Lazarus, Richard S. 1976. Patterns Of Adjustment.Tokyo:McGraw-Hill Inc.

Lontong, Eric. Susahnya Konsistensi (html://www.lontongcorp.com/2010/02/07/susahnya-konsistensi/)

Prabowo, Panji. Konsistensi. (http://pastipanji.wordpress.com/2008/07/18/ konsistensi/)

Priyadi, P.Gendra,dkk. 2008. Matematika 1 Untuk SMK dan MAK Kelas X. Jakarta: Erlangga.

Ruseffendi, E.T. 1996. Materi Pokok Pendidikan Matematika 3. Jakarta: Depdikbud.

Slameto. 2003. Belajar dan Faktor-Faktor yang Mempengaruhi. Jakarta: Rineka Cipta.

Sholeh, Achmad. Menjaga Konsistensi (http://ekspresihati.info/motivasi/ menjagakonsistensi.html)

Sudijono, Anas. 2011. Pengantar Evaluasi Pendidikan. Jakarta:PT Rajagrafindo Persada.

Sudjana, Nana. 2009. Penelitian Hasil Proses Belajar Mengajar. Bandung: Bumi Aksara.

Suh, E. M. 2002. Culture, identity consistency, and subjective well-being. Journal of Personality and Social Psychology, 83, 1378-1391.

Susilo Taufik Adi. 2009. Spirit Jepang 30 Inspirasi \& Kunci Sukses Orang-Orang Jepang. Jogjakarta: Ar-Ruzz Media.

Syah, Muhibbin. 2003. Psikologi Belajar. Jakarta: Raja Grafindo Persada.

Syarif, Reza M. 2005. Life Excellent. Jakarta: Gema Insani.

Tilaar, H.A.R.2009. Kekuasaan Dan Pendidikan Manajemen Pendidikan Nasional Dalam Pusaran Kekuasaan. Jakarta: Rineka Cipta.

Tim Penyusun. 2002. Kamus Besar Bahasa Indonesia. Jakarta: Balai Pustaka.

Tim Penyusun. 2002. Penuntun EBTANAS \& UMPTN 2002. Modul tidak diterbitkan. 